IRSTI 17.01.11

\author{
Dossanova N.Zh. ${ }^{1}$, Abdimanuly O. $^{2}$, Kapagan E. ${ }^{3}$, \\ ${ }^{1}$ Doctoral student $(\mathrm{PhD}),{ }^{2}$ Professor of the Al-Farabi Kazakh National University, Kazakhstan, Almaty, \\ ${ }^{3}$ Associate Professor of University of the Karabuk University, Turkey, Karabuk, \\ e-mail:kaznu.nazi@gmail.com, abdimanuly@rambler.ru,enverkapan@hotmail.com
}

\title{
THE FIRST RESEARCH OF LITERATURE IN THE EARLY XX CENTURY
}

The article discusses the research work of the writer Sabit Mukanov - a classic of Kazakh literature, the author of the first textbook on Kazakh literature of the early twentieth century. In addition, Kazakh literature researchers comprehensively analyze the assessment and critical views on the first scientific work on literature of the twentieth century. The analysis of the data of Sabit Mukanov on the history of this research and its significance is of great importance. Representatives of «Alash» literature: Ahmet Baitursynov, Mirzhakyp Dulatov, Omar Karashev, Magzhan Zhumabayev, Sultanmakhmut Toraygyrov, Sabit Donentaev, Berniaz Kuleev, Mukhtar Auezov, Zhusipbek Aymauytov revealed the essence of the direction of scientific work in a broad analysis.

Key words: Mukanov, research, twentieth century, Alash, literary studies

\author{
Аосанова Н.Ж. ${ }^{1}$, Әбдиманұлы Ө. ${ }^{2}$, Капаган Е. ${ }^{3}$, \\ әл-Фараби атындағы Қазақ ұлттық университетінің

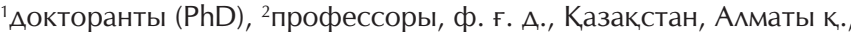 \\ ${ }^{3}$ Карабюк университетінің доценті, ф. ғ. к., Түркия, Карабюк к., \\ e-mail: kaznu.nazi@gmail.com, abdimanuly@rambler.ru, enverkapan@hotmail.com
}

XX ғасыр бас кезіндегі әдебиет туралы тұңғыш зерттеу

Мақалада қазақ әдебиетінің класигі, XX ғасыр басындағы қазақ әдебиеті туралы тұңғыш оқулықтың авторы, жазушы - Сәбит Мұқановтың «XX ғасырдағы қазақ әдебиеті» зерттеу еңбегі қарастырылады. Сонымен қатар қазақ әдебиеті зерттеушілерінің XX ғасыр әлебиеті жайлы жазылған алғашқы ғылыми еңбекке берген бағасы мен сыни-көзқарастары жан-жақты сараланады. Сәбит Мұқановтың бұл зерттеу-оқулығы кезең тарихына қатысты деректер мен нақты ақпар-дәйектер молдығымен құнды екендігі сарапталынады «Алаш» әдебиеті өкілдері: Ахмет Байтұрсынов, Міржақып Аулатов, Омар Қарашев, Мағжан Жұмабаев, Сұлтанмахмұт Торайғыров, Сәбит Аөнентаев, Бернияз Күлеев, Мұхтар Әуезов, Жүсіпбек Аймауытов шығармалары тұңғыш кеңінен талдануы кейінгі ғылыми еңбектерге бағыт-бағдар болуының мән-мағынасы ашылды.

Түйін сөздер: Мұқанов, зерттеу, XX ғасыр, Алаш, әдебиеттану.

\author{
Аосанова Н.Ж. ${ }^{1}$, Абдиманулы О. ${ }^{2}$, Капаган Е. ${ }^{3}$, \\ ${ }^{1}$ Аокторант (PhD), ${ }^{2}$ А.ф.н., профессор Казахского национального \\ университета им. аль-Фараби, Казахстан, г. А^маты, \\ ${ }^{3}$ Аоцент Карабюкского университета, Турция, г. Карабюк, \\ e-mail: kaznu.nazi@gmail.com, abdimanuly@rambler.ru ,enverkapan@hotmail.com
}

Первое исследование митературы в начале XX века

В статье рассматривается исследовательская работа писателя Сабита Муканова - классика казахской ^итературы, автора первого учебника о казахской митературе начала XX века. Кроме того, исследователи казахской митературы всесторонне анализируют оценку и критические взгляды на первый научный труд о митературе XX века. Анализ данных Сабита Муканова об истории этого исследования и его ценность имеет большое значение. Представители литературы «Алаш»: Ахмет Байтурсынов, Миржакып Аулатов, Омар Карашев, Магжан Жумабаев, Султанмахмут 
Торайгыров, Сабит Аонентаев, Берниаз Кулеев, Мухтар Ауезов, Жусипбек Аймауытов раскрыли сущность направления научной работы в широком анализе.

Ключевые слова: Муканов, исследование, XX век, Алаш, митературоведение.

\section{Introduction}

The book of Sabit Mukanov «Kazakh literature of the 20th century» is the first story about literature of the 20th century. The study was published in 1932 in Kyzylorda (Mukanov, 1932: 458). This is very rich information about the life and work of representatives of Alash-Orda with the release of the idea, the idea is subjected to ideological criticism, and for study, reprinting is prohibited.

At the beginning of the twentieth century, literature was published in the research work of the founder of the Kazakh literary scholarly science, Ahmet Baitursynov, «Literary Demonstration», published in 1926, only as an example of theoretical thoughts, as well as in the last substrate of the «Literary History» research book published in 1927 academician-writer Mukhtar Auezov.

In the work of Sabit Mukanov, for the first time, Kazakh literature of the early twentieth century was systematically studied, the history of the development of literature of the new time was comprehensively analyzed, works of outstanding creative personalities were highlighted and highlighted. In general, it should be borne in mind that the book by Sabit Mukanov «Kazakh literature of the twentieth century» is the object of study. The first is a studytextbook in a book published during the analysis of the writers 'and poets' creativity, some of the enemies, innocent punishments, in assessing their creativity, which the researcher is forced to one-time requirements. The second is to maintain loyalty to the researcher of the history of national literature, despite the difficult situation. At the same time, as in Islam, in Islam and in other Muslim countries, in Islam and in the Arab world, and in the Arab world, in Islam and in the Arab world. This means that the author, who is feeling the pressure of a difficult period, understands, understands and does not understand «what will be» calm. »He should remember that after the end of the story, his understanding is the future generation.

\section{Experiment}

It also served as a textbook along with a valuable study of voluntary demand for working time, consisting of two sections called «The Epoch of Nationalism, Wealth» and «Poets and Writers of the
Era of Nationalism». The researcher Zhandos Smagulov told about mentioned like this ... along with textbooks, research works and textbooks of Kazakh literature of the thirties. The first work manifested in this degree. Mukanov's book «Kazakh literature of the twentieth century» (Smagulov, 2012: 446). This question in the preface to the book, like the author himself, noted that «The book of literary history was written with the intention to become school supplies» (Mukanov, 1932: 6), they should understand the meaning. Since the author's book not only set the task of inventorying the history of literature, but also founded the study of new literature, and also the literature of its time. Thus, the record of literature advances, as well as flaws, and not bribes in a particularly large ideology into the system, with the indication him unfair seek to judge.

When the country acquires sovereignty and justifies our citizens of Alashorda, the work of Sabit Mukanov «Kazakh literature of the twentieth century» became the only historical factual heritage. He played a significant role in the replenishment of the white sides of our literature. This work, published in the Latin letter, has been preserved as a microfilm in national and central libraries. In this regard, direct work with this work has caused many difficulties.

On January 14, 1963, during the life of Sabit Mukanov, the Union of Writers of Kazakhstan «wrote» in 1929-30, I wrote an extensive work «Kazakh literature of the twentieth century» / nationalist era /, it was published in 1932 with a Latin letter (450 p.). As you know, the book plays a significant role in the disclosure of the rich and nationalistic ideology.

Writers 'Union, so I would like to know what kind of criticism and requirements of this book exist in our former editorial board, the Writers' Union. To this end, I saw that the book should give the Writers' Union one copy of the book, typed in a Russian letter on a typewriter. Now the word ally, «wrote a letter. But for some reason this desire did not work. After 76 years, «they returned to this book again». In 2008, the scientific works of Sabit Mukanov «Kazakh literature of the twentieth century» were written in a Cyrillic letter (384 p.) By the publishing house "Atamura», in 2012. Institute of Literature and Art named after M.Auezov reissued in the publishing house the world of literature «in volume 7 volumes of classical studies (420 pages). 
In the book «Kazakh literature of the Soviet period» published in 1998, Serik Kirabaev noted: «S. Mukanov in the book» Kazakh literature of the twentieth century (1932) has accumulated rich material about the history of literature of that era. In accordance with the political ideological trends of poets and writers, having widely analyzed their works. In accordance with the requirements of the same epoch, the uniformity of the book, caused by the statement that literature was written on the basis of the views that it was written» (Kirabaev, 1998:73).

Sabit Mukanov was published 10 years after the publication of the first twentieth-century literature research book on the history of literature of the eighteenth and nineteenth centuries, which should be written early and early according to the laws of research. In our opinion, the main reason for this is that the work of some poets and writers of the early twentieth century, which fell under the strict policy of that period, is in contact with the inner world around the history of literature. Therefore, he sought to publish literature of the twentieth century before it was found on the wheels of history.

And now it is difficult to unequivocally answer the question why Sabit Mukanov wanted to write the history of literature in which he was a witness. But, it is in our opinion. As we known, in 1932 out of 458 pages began to be signed in the 1930s. Since 1929 , in this book, no more than 60-70 percent can be spoken about poets-writers, and in the case when one cannot follow one or two words, which are spoken only to publish a bad name. From 1930 to 1988 Ahmet Baitursynov, Mirzhakyp Dulatov, Magzhan Zhumabayev and others could not say about creativity, including the names ?! When they were justified, we could learn about each other's works, so that they could read «their letters» directly into scientific use. We could not read the book's caption, 456 pages of the Sabit Latin alphabet, and found many new facts.

It is true that Sabit Mukanov, a true scholar of literary history, deserved a great deal of study of Kazakh literature in the early 20th century. The writer, who felt the pain of Soviet feelings, had a great experience in the history of the early days of the horrors of those who were shot and wounded, and knew about them, his knowledge and innocent sentences. He testified that he did not meet the requirements of the time. Otherwise, he knew that he could not play, and that he had a lot of information and valuable information about them. So he ventured.

«Having studied the literature of the 20th century, we had to write in the Kazakh literature proletarian literature, the era of prosperity, which was contrasted with the literature of the twentieth century. We do not do it in this time. In the book of the era and the proletarian era, the book was unusually large, and the second was in a hurry. That is why we left the prosperity of the epoch of the proletariat in the literature the next day» (Mukanov, 1932: 8), writes Sabit Mukanov in the clear. It should be noted that the study of the history of Kazakh literature from the beginning of the twentieth to the twentieth century is called "nationalist, rich literature» and «proletariat literature». Researcher Zhandos Smagulov said: "If you take this point of view seriously, then in the early twentieth century, works of Kazakh literature were studied, which could only be considered as oral and written literature in the works of $\mathrm{M}$. Auezov and G. Dosmukhamedov», «literature XVXVI Century and XVIII-XIX Century of Poets», and in S. Mukanov» The Age of «Kazakh Literature of the XX Century». It is worth noting that a positive approach to the study of literary heritage began in 1925 , and it is noteworthy that this is a new step in the era of the history of the history of literature in the period of the birth of the Kazakh science of literature» (Smagulov, 2012: 177).

In the first part of the study, the author developed the stages of visiting the history of «nationalist» literature, consolidating his thoughts about the state of the Kazakh people, social and public life, nationality, nationalism, and their «alashordi» organization. In the meantime, he was talking about his platform. Then he began to study the main purpose of his literary history in relation to his era. Research Sabit Mukanova - not a primitive world. According to time, research is a serious search that can put full responsibility for employment. This is a productive work, which is an energetic experience, which is a complex phenomenon in the literary science of the 30 s.

The literary scholar Tursynbek Kakishev recognizes the book of Sabit Mukanov «Kazakh literature of the twentieth century» as one of the earliest works in the history of Kazakh literature of the first centuries, covering the first quarter of the twentieth century (Kakishev, 1995: 131), Sabit Mukanov himself said that he would give social and artistic significance in his works. The purpose and significance of Tursynbek Kakishev is that the "Kazakh literature of the twentieth century» by Sabit Mukanov is not used to sacrifice the merit of monumental work, but to improve the history and complicate it (Kakishev, 2000: 220), «Respect for the true composer of the history and value of literature». The idea of Sabit Mukanov corresponds to the statement of Tursunbek Kakishev: look at the country, comment, break 
the fragmented material into the system and check the cause of each work» (Mukanov, 1932: 11). In this article we have tried to follow the consistent conclusion made by our famous scientist Tursunbek Kakishev.

The researcher systematized his own research methodology, the direction he followed, and the scientific «sign». «In the literature there is an overwhelming part of the research. For example: history, logic, methodology, criticism of literature, and so on. Of these, our task was to write a story. In other words, the opinion of that era that we explored was: how it progressed, how it came back, what caused it. We spread it much more widely in history. In many places we have reviewed some of the originals, the reasons for the origin of the work, the internal and external design and our own criticism. In some cases, we managed to talk less about art and research methods. In some places, we focused on language, rhythm, artistic side and logic. All this, of course, was not done. This was intentional. In the end, this book is the first textbook in the world, although it has a history of a certain age. Our schools are still poor teaching aids as knowledge of literature. Therefore, we understood that, going beyond the scope of history, it is useful to provide information both from other systems of literary studies and from other systems of literary studies» (Mukanov, 1932: 7). That is, this book of Mukanov - This is not only a scientific monograph studying the life and work of poets and writers, but also a systematic and complex scientific work based on the formation of literary knowledge of a textbook of the 20th century, although the goal of cognitive systems in literature is to differentiate the consciousness of absorption.

During this work, different opinions were expressed. As is well known, in connection with politics, such opinions as work written in the years after the October Revolution prevail, but we are faced with the task of rethinking them from the point of view of modern free opinion. The famous scientist T. Kakishev wrote in the early 90s that «the truth about the authenticity and development of Kazakh literature of the twentieth century was not written after the 1932 book by S. Mukanov» (Kakishev 2000: 218).

Elzhas Bekenov wrote in his book National Movement and Nationalist Literature (1935), in which the book of Sabit Mukanov was published in the booklet, after which he published a semi-recorded critical article: «The History of the Kazakh People. But there is no record of this date. The story of Sabit is part of Kazakh history. The history of literature in certain epochs. This is the most valu- able work in the Kazakh literature. There is nothing wrong with this kind of work and value» (Bekenov, 1935: 5). «Criticism of Mirzhakip Dulatuly, Magzhan Zhumabayev, Omar Karashuly, especially Sultanmakhmut Toraygyrov, Mukhtar Auezuly (Bekenov, 1935: 67). Instead of challenging actions a coup, it's a pity that you don't understand the revolution of the proletariat». (Bekenov, 1935: 67), - says Mukanov's criticism of Alash. This is a clear sign that his colleagues assess Sabita Mukanova differently.

«Especially the criticism was frustrated», - that Sabit Mukanov says about Sultanmahmut Toraygyrov, why he remained unchanged. The researcher said: «We have already mentioned Sultanmakhmut as a nationalist poet, and we gave him a full argument. Why is a rich poet so poor? Poverty and wealth can be questioned as to whether one or more of two opposing views can be applied to one person. In Sultanmahmut there is a difference between other rich writers. He is basically a rich man, but he cannot see the shortcomings of a poor man when he enters, as he says, «Prince» (Mukanov, 1932: 305-306), - says the work of Sultanmakhmut. After analyzing his poems «Anau-Minau», «Kymyz» as proof of his own opinion, he seeks to show the nature of Sultanmakhmut. He appreciates the work of Sultanmahmut and speaks honestly. Further, when he says: «When artifacts have a good artistic character», verse «The thought of the disciple»:

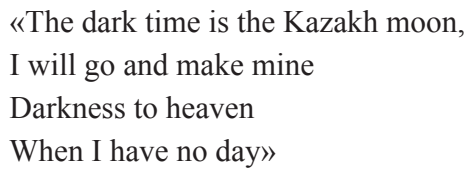

- he was honored with the highest level of optimism, filled with romanticism, and he was justified by a truthful poet. He feels the power of his fiery poems with the power of justice, and he openly expresses his judgment. «In general, Sultanmakhmut is a strong poet, a poet who occupies a large place in the Kazakh literature. A poet who needed a new study» (Mukanov, 1932: 345).

In one of these conclusions, Sabit Mukanov, the pseudonym of the poet Sabit, a sophisticated political analyst, defeated Sabit's poetry, and his purity in the study of poetry is a critical critic, sophisticated research ability. Every critic of time . According to the researcher, Sultanmakhmut took his place in the history of Kazakh literature and gave a lot of research, good results and fruitful results. Evidence of this - B. Kenzhebaev (Kenzhebaev, 1966: 184), Y. Duisenbayev (Duissenbaev, 1965: 
331), A. Espenbet Espenbetov, 1992: 200) and other works. One of them was engaged in creativity, poetic talent, taking the place of Kazakh literature, one of the poet's «patriots» for life, defining civil identity and discovering the eternal legacy of eternal heritage.

In his work, Sabit Mukanov wrote Sultanmakhmut as a rich nationalist, and if we try to prove it, we must consider this time, the policy. Why not write a poem about the poet who wrote the poems «Alash», «Tanystyru» and «Aitys» in 1932.

One of the eminent representatives of Kazakh literature and one of the eminent representatives of Kazakh literature of the early 20th century, Sabit Mukanov's study was Sabit Donentaev. In his study, Sabit Mukanov also referred to the group of rich nationalist poets. From the same point of view analyzes verses. His poems in the collection «Uah-tüyek» («Uah-tuyek»), through which you can determine the main directions of the poet's creativity.

One example is the poem «On the Knowledge of the Kazakhs».

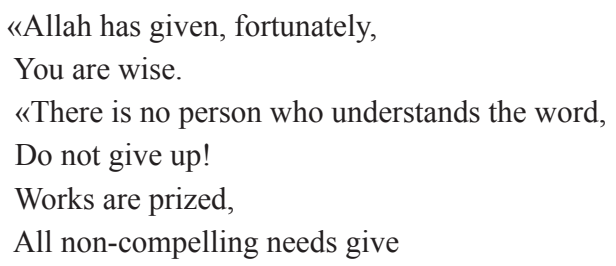

«Here he worships nationalist leaders as Gods», - says the researcher, «that he returns with his heart and goes where he leads» (Mukanov, 1932: 348). Of course, we know who Sabit Mukanov refers to and what he is going to do. At some point, one of them could not write a book with praise or customization. We have no right to deny that a researcher does not like such verses when they are called upon to be enemies of the people. This is not the only Sabit Mukanov, but the whole idea of that time. So it was accepted, so it was acceptable. Sabit Mukhanov, who made such an idea about poets and writers, also worked hard on his spiritual leaders.

The youngest of them analyzes the works of M. Auezov, such as «Ogygan Azamat», «Kily Zaman», «Karakoz», «Enlik-Kebek», «Kokserek». Of course, in his analyzes he speaks the truth when he speaks about the purely creative aspect of the poetwriter, although he is more than a singer. This is a great success of this work. For example, researcher Kokserek says the following: «Kokserek cannot be considered a purely hunting experience. Here is a big political background. This story should be the end of the rich idea of Mukhtar. He does not expose the internal contents of the body to the pallet without the worker's work» (Mukanov, 1932: 417).

In this case, it is not difficult to understand that in the Kazakh literature does not apply to the nature of fearless conversation. We value the researcher M. Auezov, and in his speech told about creativity: «When the poetic, writing power, Mukhtar is a powerful writer. At the top of the beauty of the language Mukhtar is able to create. During the meeting, issues of cooperation between Kazakhstan and China, as well as current issues of the international agenda of the day». (Mukanov, 1932: 417). Here is the truth.

As for the writers Alash-Orda - A. Baitursynov, M. Dulatov, M. Zhumabayev on the pages devoted to writers and poet Sabit Mukanov, of course, showed great criticism and made every effort to reveal the rich, nationalistic nature. But when it comes to being creative, then it is about the edges of their poetic writing skills. Mukanov made sharp and sharp reviews, which are still valid today. Our main goal is that the first study at the beginning of the twentieth century was set forth about the literature of the twentieth century, found an opinion about the shortcomings of work, combined with time and time, involvement in today's heights of consciousness, and further promote rational conclusions that can be undertaken for further research.

«One of the first works of A. Baitursynov is called «Kirik Mysal», because the poet translated «forty examples of the Russian poet I.K Krylov» (Mukanov, 1932: 102) About the department. «Kirik Mysal» Sabit Ahmet is built as follows. 1. «Swan, Shortan and Shayan». This theme emphasizes: «When writing this verse, Krylov's Swan is a nobleman, a shorts dealer and a bearded blackberry. «Krylov supports each other, and Ahmet speaks Kazakh». (Mukanov, 1932: 106). 2. Old age is «Old Lion» Knot: «This is a common fable, an old-fashioned song that went against the invading slaves» (Mukanov, 1932: 107). 3. The translation «frog and bull» is translated as «behavior, pride» (Mukanov, 1932: 109).

Next topic I think the most convincing and informative opinion of Mukanov. Here the researcher discovered all the realities of Akhmet Baitursynov's creativity. The basic idea is to focus on learning here». 4. Against the king. «Unlike Krylov, A. Baitursynov speaks about the brutality of the actions of the colonial government against the Kazakh people. For example, "Good fox ...». Here orphans are not orphans who do not have a father in the village, but Kazakhs. Because Ahmet called 
a Kazakh named «orphan» (Mukanov, 1932: 111).

While Ahmet was in Orenburg in 1911, and the last two «Masal» collections were published in Kazan in 1922, the researcher analyzed the poems of A. Baitursynov and systematized their ideas. He strove for a deeper knowledge of his activities in the Awakening of consciousness, to reveal the meaning of his poems «Soz iesine», «Akyn inim»:

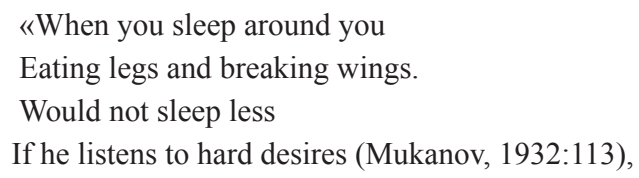

- he says: «The political course is to wake the sleeping ears of those who sleep». Of course, this is the Kazakh nation», - says Mukanov, 1932: 114. In his poem «Akin inim» he punished those who did not help the Russian authorities, who did not help the nation» (Mukanov, 1932: 119) reveals the nature of poetry and the subtle truths of the word about which he speaks. There is no need to worry about repeating the word «nation» repeatedly. Is this not spiritual leader Ahmed?

Sabit Mukanov, in his work 58 years ago, commented on his personal opinion, as well as his personal creativity, since it turned out to be a chronicle of the present when the publication of the newspaper Kazakh was published in the 90s. By sponsoring the rich, a nationally minded newspaper funded by them cannot ignore their honest opinion. Kazakh language was born in Kazakh language. Purely Kazakh was the only newspaper in Kazakh (Mukanov, 1932: 52). Looking back at this opinion, the Kazakh newspaper thought about a newspaper published in 1929 by Ahmet Baitursynov, who was sentenced to 10 years. This idea is a sign that Sabit Mukanov could not escape the honesty of the research.

At the same time, before the revolution, the Soviets did not settle, and the poet Sultanmakhmut Toraigyrov criticized the poems of Mirzhakyp Dulatov. Mukanov also criticizes his novel «Unhappy Jamal» - the first Kazakh novel at its level. The first researcher at the beginning of the twentieth century Mukanov: «In this novel, first of all, freedom of a woman sounds, and on the other hand, the old religion, the old tradition, the novel against the old habit. This is a novel that hit the new rich Kazakh people. That is why the novel was read aloud from the Kazakhs, the country and the novelists. Gali could not be a great example for a country guy who wanted to be a victim. Jamal was a great example for a village girl. Immortal novels were published by «Munly Maryam» (Salim Kashimuly), imitating Unhappy Jamal. «The unfortunate Jamal» until recently was an example for many writers». (Mukanov, 1932: 152) - the novel «Unhappy Zhamal» at the beginning of the 20 th century was replaced by complex works of art, Roman, as a novel, clearly proves its leadership task.

\section{Results and discussion}

Writing the work of Sabit Mukanov «Kazakh literature of the twentieth century», published 87 years ago, can not be overlooked in the light of modern times. Nevertheless, the abundance of evidence-based sources related to the history of literature, the abundance of thoughtful thoughts and ideas of literary criticism, will greatly increase the value of this book as a work.

In general, this work of Sabit Mukanov is primarily related to the fact that historical data and factual data are absorbed, and secondly, when writing the history of Kazakh literature of the twentieth century, one system those are historical value.

At the same time, it also stands in a broad analysis of well-known Alash veterans: Ahmet Baitursynov, Mirzhakyp Dulatov, Omar Karashev, Magzhan Zhumabayev, Sultanmakhmut Toraygyrov, Sabit Donentayev, Bernaz Kuleev, Mukhtar Auuzev. Also known as Akhmet Mametovich [Mukanov, 1932: 39], Kenzhegali Gabdollin (Mukanov, 1932: 40), Bilal Suledzhuly, Zhunis Babatay [(Mukanov, 1932: 72), Koshke (Koshmukhambet), it is desirable that Kameshchenovy (Mukanov, 1932: 79) took examples from their poems and examined their names. Halel Dosmukhameduly (Mukanov, 1932: 89), whose books were published in those years in his «nationalistic» thinking, historical significance and inconsistency contributed to the significance of the studies of Halel Dosmukhamedov, who made significant contributions to literary studies.

All this leads to the fact that the name of many poets, writers and prominent public figures, are «alashors» by citizens who love their nationality, and creates the basis for self-expression about them. In this regard: «a lot of documentary work was not written about our literature of the early twentieth century, especially about participation in the Alash movement». (Kakishev, 1992: 218).

The main achievement of the study and textbook is the encyclopedic value of the political and ideological, social, social, spiritual and cultural problems of the early twentieth century. Given the fact that he could cover the history of the 
development of Kazakh literature at the beginning of the 20th century, he was always the first to write literary works on a scientific basis and never lost his place in Kazakh literary criticism.

\section{Conclusion}

In conclusion, our work is the «Kazakh literature of the twentieth century» by Sabit Mukanov, which is a valuable contribution to the Kazakh literary science. Although controversies arose during the ideological debate, there are many innovative ideas, conclusions and conclusions. This is a valuable book that led to methodological research in the teaching of literary history, since it focuses on literary and scientific research in its time, as it is research and study. The scientific work of Sabit Mukanova was always the first to study the literature of the twentieth century, and remains the golden stock of historical data necessary for Kazakh literature. He must have witnessed the period of history, who witnessed history and experienced great changes in his life, and that there was no doubt about the truth of time.

\section{Литература} 458 б.

Мұқанов С. ХХ ғасырдағы қазақ әдебиеті (Ұлтшылдық, байшылдық дәуірі әдбиеті). - Қызылорда: Қазақстан, 1932. -

Смағұлов Ж.Қ. ХХ ғасырдағы қазақ әдебиеттану ғылымы. - Қарағанды, 2012. - 446 б.

Қирабаев С. Кеңес дәуіріндегі қазақ әдебиеті.- Алматы: Білім, 1998. - 224 б.

Кәкішев Т. Кер заманның кереғар ойлары. - Алматы: Атамұра, 1995. - 168 б.

Кәкішев Т. Сәбең өткелдері. - Алматы: ҚАЗақпарат, 2000. - 320 б.

Бекенов Е. Ұлт қозғалысы және ұлтшылдық әдебиет. - Қызылорда, 1935. - 72 б.

Кенжебаев Б. Ө. Есназаров XX ғасырдағы қазақ әдебиеті. - Алматы: 1966. - 300 б.

Дүйсенбаев Ы.Т. Қазақ әдебиетінің тарихы. - Алматы: Ғылым, 1995. - 524 б.

Еспенбетов А. Сұлтанмахмұт Торайғыров. - Алматы: Ғылым, 1992. - 200 б.

Кәкішев Т. Санадағы жаралар. - Алматы: Қазақстан, 1992. - 264 б.

\section{References}

Bekenov E. (1935). Ult qozgalysy jane ultshyldyq adebiet. [National Movement and Nationalist Literature.]. Kyzylorda, 72 p. (In Kazakh)

Duisenbaev I. T. (1995). Qazaq adebietining tarihi. [The history of Kazakh literature.]. Almaty: Gylym, 524 p. (In Kazakh)

Espenbetov A. (1992). Sultanmahmut Toraigyrov. [Sultanmakhmut Toraygyrov.]. Almaty: Gylym, 200 p. (In Kazakh)

Kakishev T. (1995). Ker zamannyng keragar oilary. [Contradictory thoughts of time.]. Almaty: Atamura, 168 p. (In Kazakh)

Kakishev T. (2000). Sabeng otkelderi. [Passages of carp.]. Almaty: Kazakh information, 272 p. (In Kazakh)

Kakishev T. (1992). Sanadagy jaralar. [Sorcerous Wounds.]. Almaty: Kazahstan, 204 p. (In Kazakh)

Kenzhebaev B. Esnazarov O. (1966). XX gasyrdagy qazaq adebieti. [Kazakh literature of the twentieth century.] Almaty, 300 p. (In Kazakh)

Kirabaev S. (1998). Kenes dauirindegi qazaq adebieti. [Kazakh literature in Soviet times.]. Almaty: Bilim, 224 p. (In Kazakh)

Smagulov J.G. (2012) XX gasyrdagy qazaq adebiettanu gylymy. [Kazakh literary criticism of the 20th century.]. Karaganda, 446 p. (In Kazakh)

Mukanov S. (1932). XX gasyrdagy qazaq adebieti. [Kazakh literature of the 20th century.]. Kyzylorda: Kazahstan,458 p. (In Kazakh) 